\title{
色材協會 誌
}

第 18 卷第 9.10.11 號昭和 19 年

\section{一翰安一}

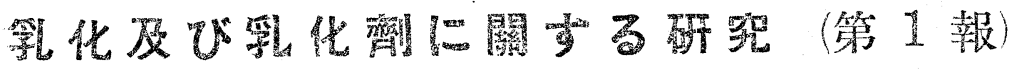

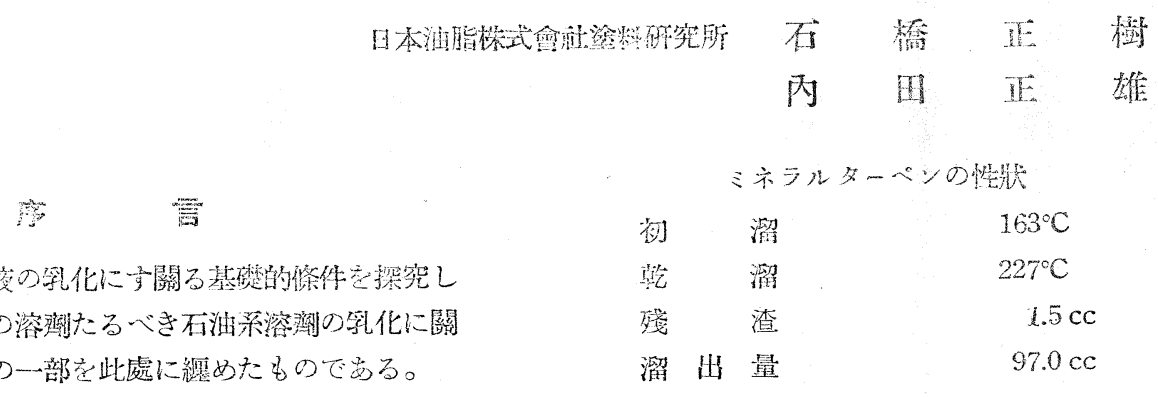

\section{實驗}

\section{ミネラルターペン及びエステルガムの特數測定}

シテラルーペンの特數測定

[1]米蒸溜ミネラルターペンの分別蒸溜試驗

供試ミネラルターペンは淡黄色を呈し此れを日本標準 規格染料用油類試驗方法第 235 號類別 K47 頁 4 第十 五條分溜試驗乙法に依り分別蒸溜試驗孝試みたる結果は 次の如くである。

$$
\begin{gathered}
\text { 第 一 表 } \\
\text { ミネラルターペンの分別蒸溜値 }
\end{gathered}
$$

蒸溜溫度

$170^{\circ} \mathrm{C}$ 迄

$180^{\circ} \mathrm{C} "$

$190^{\circ} \mathrm{C} "$

$200^{\circ} \mathrm{C} " \prime$

$210^{\circ} \mathrm{C} "$

$220^{\circ} \mathrm{C} " \prime$

$226^{\circ} \mathrm{C} "$
溜出量 $\mathrm{cc}$ 數

$7.8 \mathrm{cc}$

$26.5 "$

$53.5 "$

$74.5 \prime \prime$

$89.0 " 1$

$96.5 \prime \prime$

$97.0 "$
上表に示せる如く分別蒸溜せるミネラルターペンの性狀 、は次表の如くである。
日本標潐規格に依れば染紏用のミネラルスピリットは同 規管十三條ミネラルスピリットの項に值り

$150^{\circ} \mathrm{C}$ 迄の溜出量一 $5 \%$ 以上(減失量を加算す)

$190^{\circ} \mathrm{C}$ 迄の溜出量— $85 \%$ 以上(減失量を加算す) 乾 默- $-205^{\circ} \mathrm{C}$ 以下

であるが本品は第一表に見る如く相當多量の高沸點分を 含有するから此れを一度再蒸溜に依り高沸點分を除去し て使用することとする。再蒸溜の方法は「5リットル」丸 底フラスコに依り $205^{\circ} \mathrm{C}$ 迄蒸溜し高沸點分を除去す。再 蒸溜のミネラルターベンを分別蒸溜した結果は次表の如 くでもる。

$$
\text { 第 二 表 }
$$

再蒸溜ミネラルターペンの分別蒸溜值 蒸溜温度

$130^{\circ} \mathrm{C}$ 溜出量 $\mathrm{cc}$ 數

$140^{\circ} \mathrm{C}$ $3.0 \mathrm{cc}$

$150^{\circ} \mathrm{C}$

$4.0 \mathrm{cc}$

$160^{\circ} \mathrm{C}$

$7.8 \mathrm{cc}$

$170^{\circ} \mathrm{C}$

$19.3 \mathrm{cc}$

$180^{\circ} \mathrm{C}$

$53.1 \mathrm{cc}$

$190^{\circ} \mathrm{C}$ 87.9 cc 
$200^{\circ} \mathrm{C}$

$95.2 \mathrm{cc}$

上表の如き分別蒸溜せる再蒸溜ミネラルターペンの性狀 は次表の如くである。

$$
\text { 再蒸溜ミネラルターベンの性狀 }
$$

\begin{tabular}{|c|c|c|}
\hline 初 & 溜 & $115^{\circ} \mathrm{C}$ \\
\hline 乾 & 點 & $204^{\circ} \mathrm{C}$ \\
\hline 残 & 渣 & $1.0 \mathrm{cc}$ \\
\hline 溜 出 & 量 & $97.9 \mathrm{cc}$ \\
\hline
\end{tabular}

分別蒸溜の結果に依れば日本標準規格に大體適合する故 本品を試料として今後の研究に使用することとした。

[2]再蒸溜ミネラルターペンの比重测定

恒溫槽 $\left(\frac{20^{\circ}}{20^{\circ}} \mathrm{C}\right)$ に於て比重計に依り 30 分間浸漬して 唧定要。

比重測定值は 0.804 であつた。日本標準規格に依ると 比重 $\left(\frac{20^{\circ}}{20^{\circ}} \mathrm{C}\right)$ に於て 0.780 以上なる故試料は日本標準 規格に合格寸る。

\section{エスデルガムの特數測定}

[1]酸價の测定

供試エステルガムを日本標準規格ロジン及びェステル ゴム試驗方法第 398 號類別 K78 頁 2 第四條酸價に依 りて測定したる結果は次の如くである。

$$
\text { 酸價測定值一 }-15.0
$$

日本標準視格に依ると塗料用のエステルガムは同規格の 第 397 號類別 K75 第三條の項に依り酸價は 10 以下な るを以て酸價少しく大に過ぐ。

[2] 軟化點の测定

日本標準規格ロジン及びェステルガム試驗方法第 398 號類別 K78 頁 1 第三條軟化點に依り測定せる結果は次 の如くである。

$$
\text { 軟化點測定值 }-87^{\circ} \mathrm{C}
$$

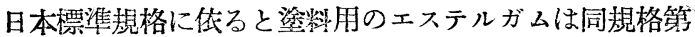
三條軟化點の項に依り $70^{\circ} \mathrm{C}$ 以上なるを要す。一般に瑱 化點の高きことは優良品なるを證明するものである併し 乍ら本品は既に述べたる如く酸價が高いから此れが品位 決定に就いては次の如く灰分の测定を行ふものとする。

[3]灰分の測定

日本標準規格ロジン及びェステルガム試驗方法第 398 號類別 K 78 第五條灰分に依りて测定した結果は次の如: くである。

$$
\text { 灰分測定値一 } 0.66 \%
$$

日本標準嫢格に依ると塗料用のエステルガムは同規格の 第三條の項に伡り灰分 $0.5 \%$ 以下に比し本品は大體適合 する故今後の㗏究試料として使用せんとす。
上述の如く測定試驗せるミネラルターペン及びェスデ ルガムの性狀を一括して示すと次表の如くである。

$$
\text { 第 三 表 }
$$

ミネラルターペン及びェステルガムの特數表

$$
\text { ミネラルターペン }
$$

エステルガム

比重一 - 0.804

分別蒸溜値は別表揭載

$$
\text { 酸 價一 } 15.0
$$

軟化點- $-87.0^{\circ} \mathrm{C}$

灰 分- $0.66 \%$

分別蒸溜曲線

(1)——蒸溜ミネラルターペン

(2)一一再蒸溜ミネラルターペン

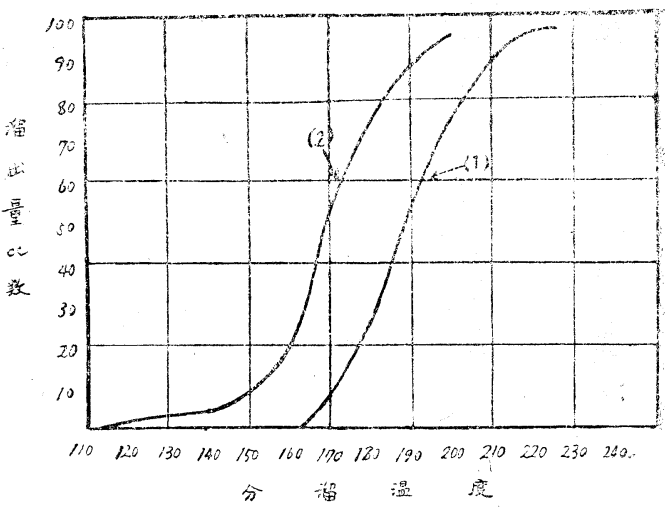

\section{オレイン酸リ゙ーダに依るミ录ラル ターペンの攽化}

代表的の樹脂としてェステルガム溶液の乳化研究に當 り此れろ゙溶劑たるべきミネラルターペンの乳化を研究す るものである。本項に於てはミネラルターペン及び水を 一走にしてオレイン酸ソーダの最適量を喍究することと した。例してオレイン酸ソーダの表示法としてはミネラ ルターペンに對する重量\%を探用したるのである。

乳化臍(オンイン酸ソーダ)——溙油脂肪酸の液體酸分 を茊性ソーダに依りて中和せるものにして本品 は粉末狀のオレイン酸ソーダで製造後長時日を 經過し酸價の測定に依ると $26 \%$ の遊離オレイ ン酸を含有するものである。

第一篩 ミネラルターペン 60 對水 40 の場合 ミネラルターペンに對して 1.5-4\%のオレイン酸ソー。 ダを含むエマルジョンに就いて乳化機にて處理せる結果 を次表に示す。 


\begin{tabular}{|c|c|c|c|}
\hline 乳化䬕\% & 乳化機處理數 & 爿 & 態 \\
\hline 1.5 & 2 & WO 型 & 油層分離 \\
\hline 2.0 & 2 & 同 & 上: \\
\hline 3.0 & 2 & 同 & E \\
\hline 4.0 & 2 (1四で十分) & OW 型 & 優良 \\
\hline
\end{tabular}

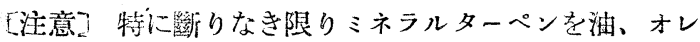
イン酸ソーダを石龉と略記す。

第匹表の如く OW 型エマルジョンの生成は石羷湢度 $4 \%$ 以上たるを要す。 $4 \%$ の安定度は 480 時間 (20日) にして極少の水を分離するが 1 ケ月保存後も輕く振晹す るときは元の狀態になる。上記の實驗を逐行中乳化機處 理の前に試料を相當時間振湯或は㩭拌等するときは乳化 機處理に依りて生成するエマルジョンの狀態が明らかに 改善せられたることを認めたる故次に乳化機處理の前處 理として振湯の效果を檢討した。

$$
\text { 第 五 表 }
$$

振燙處理の効果

\begin{tabular}{|c|c|c|c|}
\hline 乳化劑\% & 抎盪時間 & 乳化機處理數 & 態 \\
\hline 0.5 & 連續 15 分 & OW 型, & 二層分離 \\
\hline 0.5 & 連續 40 分 & 同 & 上 \\
\hline 1.0 & 連續 15 分 & 2(1包で十分) OW 型 & 良好 \\
\hline 1.5 & 上 & ) OW 型 & 優良 \\
\hline 2.0 & 同 & $2($ 同上) & 上 \\
\hline 3.0 & 同 & $2($ 同上) & 上 \\
\hline 4.0 & 上. & $2($ 同上) & 上 \\
\hline
\end{tabular}

上表の場合と同樣な試料に就いて 168 時間 (7 日)時間 を切つて振湯處理した結果を次婊に示寸。

$$
\text { 第 六 表 }
$$

\begin{tabular}{|c|c|c|c|c|}
\hline 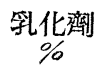 & 荗化機處理數 & 實驗直後 & 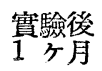 & 實驗後隽 \\
\hline 1.5 & 2(1闰で十分 & $\begin{array}{l}\text { OW } \\
\text { 型優良 }\end{array}$ & $\begin{array}{l}\text { OW } \\
\text { 型優良 }\end{array}$ & 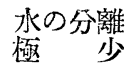 \\
\hline 2.0 & 2 (同) & 同上 & 同 上 & 同 \\
\hline 3.0 & 2 (同) & 同上 & & \\
\hline
\end{tabular}

168 時間 (7 日) 振湯處理の効果

第五表に示せる如く振湯處理さ行ふときは石龄浱度 1 \%以上たるを要す、安定性は實驗後 25 日の觀察による と石劇濃度 3-4\% は最子安定で $2 \%$ 及び $1 \%$ は稍及少 る。第四表及び第五表に依孔ば石澞の使用量を增寸と共 にWO 型の量を減じ安定性を堙加し一定量以上の使用 に依つて優良なる OW 型エマルジョンを得られること が解る郎ち振濫及び乳化機處理によりて油粒子が均一な 微粒子に分割し表面積が大となるが此の增大せる表面積 ふ應じて多量の石签の存在が OW 型エマルジョンの安
定度を保つために必要である。第六表の時間を切つて長 時間振温の場合は水中に於ける石鹼が解離して種々なる 石䠯分子が油粒子の界面に吸着する速度の促淮が考へら れる。吸着の機構に就いては Langmuir 氏は石裣分子 は極性原子團 $\left(-\mathrm{CO}_{2} \mathrm{Na}\right)$ と無極性原子團 $\left(\mathrm{CH}_{3}\right.$ 基 $)$ 上 り構成され $\mathrm{CO}_{2} \mathrm{Na}$ は親水性にして $\mathrm{CH}_{3}$ 基は親油性が 大なるものと云はれる。其㣗故に OW 型ェマルジョン の生成は石䲓分子の無極性部分は油相中へ埋沒し極性部 分を哭出して吸着してるる。又 Harkins 氏は水と油よ り構成する WO 型エマルジョンの石龄分子の吸着配列 膜は間隙を生じて不安定であると結べてるる。

\section{ミミラルターペン 65 對水 35 の場合}

前に乳化機處理の場合及び此れが前處理して振沮處理 を行ふ場合はェマルジョンの生成と安定度に大なる効果 を示するのであることを認めた。本項に於ては油 65 對 水 35 の場合を探究した。乳化條件は前と同樣である。 次に乳化機處理の場合を次の表に示寸。

$$
\text { 第 七 表 }
$$

$\begin{array}{cll}\text { 乳化劑\% } & \text { 乳化機處理數 } & \text { 狀 態 } \\ 0.5 & 2 & \text { OW 型+WO 型 } \\ 1.0 & 2 & \text { 同 上 } \\ 2.0 & 2 & \text { 同 上 } \\ 3.0 & 2 & \text { WO 型。下部は油層 } \\ 3.5 & 2 & \text { 同 上 } \\ 4.0 & 1 \text { (1 回で十分) } & \text { OW 型。優良 }\end{array}$

上表の場合と同樣な液に就いて振湯の効果を實驗し結果 を次表に示す。

\begin{tabular}{|c|c|c|c|}
\hline 乳化劑。 & 6 振晹特間 & 乳化機處理 & 態 \\
\hline 0.5 & 連續期15 分 & 2 & 殆OW型 二若分離 \\
\hline 1.0 & 同上 & 2 & OW型 二層分離 \\
\hline 2.0 & 同上 & 2 & OW型 粗粒 \\
\hline 3.0 & 同上 & 2 & OW型 優良，粘度大 \\
\hline 3.5 & 同上 & 2 & 同 \\
\hline 4.0 & 同上 & 1(1间で十分) & 同 \\
\hline
\end{tabular}

第 八 表

振燙處理の効果

第七表乳化處理の場合は石龉濃度得 $0.5 \%$ より $2 \%$ 迄、 二重型エマルジョンを生成し此等ェマルジョンは石覻の

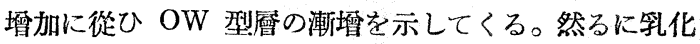
機處理の前處理として振盪處理を行ふときは第入表の如 く石礆濃度 $2 \%$ 以上で乳化する。安定度は第七表 $4 \%$ の場合は 288 時間 (12 日) の經過によると水層分離管 向を認めたが第入表 $3 \% 、 3.5 \%$ 及び $4 \%$ は 720 時鿼 
(1ヶ月)の安定度を保つもので娄つて水の分離は時間の 霄加と共に $2 \%$ が最大で $4 \%$ 、3\% 及び $3.5 \%$ の順位. により分離度を減少する。本項の場合は石䩎の濃度 3.5 \%を最適と認めた。

上述の如く振盪處理の効果は極めて著しいことが解る。

\section{ミ录ラルターペン 70 對水 30 の場合}

ミネラルターペンに對して石甗濃度 0.5\%より6\%を 含有する油 70 對水 30 の場合エマルジョンの狀態に就 きて探究する乳化の條件及び操作は從前通りとし乳化機 處理の場合を次表に示寸。

\begin{tabular}{|c|c|c|}
\hline & 第 & 表 \\
\hline 乳化齋\% & 乳化機處理數 & 狀 態 \\
\hline 0.5 & 3 & OW型+WO型 二觰分離 \\
\hline 1.0 & 3 & 同上 \\
\hline 1.5 & 3 (2巨で十分) & $\begin{array}{l}\text { OW 型、WO 型極少 } \\
\text { 二厤分離、粘大 }\end{array}$ \\
\hline 2.0 & 3 & 同上 \\
\hline 3.0 & 3 & OW型.WWO型極少稍安定 \\
\hline 4.0 & 3 & OW型、WO型極少二曆分離 \\
\hline 5.0 & 3 & OW型+WO型 二㒶分離 \\
\hline 6.0 & 3 & 同上 \\
\hline
\end{tabular}

上表の場合と同樣な液に就いて振盪の効果を實驗し其の 結果を次表に示す。

\section{第 十 表}

振盪處理の効果

\begin{tabular}{|c|c|c|c|c|}
\hline 乳化牕 & 振溋時| & & 管化機 & 狀 \\
\hline 0.5 & 連續15 & & 2 & OW型、WO型極少二厤分離 \\
\hline 1.0 & 同 & 上 & 2 & 同上 \\
\hline 1.5 & 同 & 上 & 2 & $\begin{array}{l}\text { OW型+ } \mathrm{WO} \text { 型OW 型層大二曆 } \\
\text { 分離 }\end{array}$ \\
\hline 2.0 & 同 & 上 & 2 & 同上 \\
\hline 3.0 & 同 & 上 & 2 & 同 \\
\hline 4.0 & 同 & 上 & 2 & 同 \\
\hline
\end{tabular}

5.0 同上 2 同上

6.0 同上 2 OW 型 優良 粘度大

第九表の示寸如く本實驗に於ては最適量は見出し得な かつた。算十表振湦處理の狀況を述べると6\% 型優良エマルジョンを生ずる。此れは粘度極めて大なる ため乳化機處理に時間を要す、安定度に就いては 360 時 間(15 日)の狀態に依ると水の分離傾向を示し 720 時間 (1ヶ月)の經過によると完全に水曆を分離する。本項實 驗に際して次の樣なことが推定される。理論的に述べる と一定容器に等しい㨁俓の球を最密充填のときの內相の 占むる全容積は全體の 74\% で外相の占むる容積は $26 \%$ である。然るに實際のエマルジョンに於ては內相を包む 外相郎ち莫に或る厚さがあるものと考へられる。從つて 油粒子が均一に分散するから全體の容積に對する內相の 全容積は理論值より小になる筈である。又油粒子に大小 があれば理論上より多量の內相を分散せしもることが出 來る郎ち石䶨濃度を增加するときは油粒子は乳化機によ りて均一に分散され同時に吸着界面償も厚くなると考へ られる。碰して斯樣なことは一定容積の外相中に分散せ しめられる內相の容積を限定するに効果的であると考へ

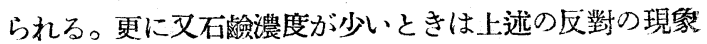
を呈するものと推定される。

\section{オレイン酸ソー朵に依るミ录ラルターペンの乳 化に對するアルカリ添加の効果に就いて}

石裣水溶液にアルカリを添加するときは油との間の界 面涱力を著しく低下゙せしるものである(石嶮化學 42 頁 參照) 又はアルカリ其他電解質の存在に依つて石㓺の解 離が抑制されて中性ミセルの量を增加するるのである。 次に石虚に依るミネラルターペンの乳化に對寸るアルカ リ添加の影響を檢討した。

$$
\text { 試料— }-0.1 \mathrm{~N} \text { 苛性ソーダ溶液 }
$$

石劄濃度 $1 \%$ に於ける油 60 對水 40 の場合アルカリ添 加による効果を實驗し結果を次表に示す。

第 十 一 表

\begin{tabular}{cc} 
アルカリ添加量 & 石鹼濃度 $1 \%$ 場合 \\
cc 數 & \multicolumn{2}{c}{ 狀態 } \\
2.0 & OW 型+WO 型 \\
3.0 & 同 上 \\
3.5 & OW 型 粗 粒 \\
4.0 & OW 型 優 良 \\
4.5 & OW 型 良 好 \\
5.0 & 同 上
\end{tabular}

$\overline{4(9.10 .11)}$ 
上表實驗と同樣な條件によりて石䖒濃度 $0.5 \%$ の晹合に 就きて實驗し結果を次表に示す。

\begin{tabular}{cc} 
& \multicolumn{2}{c}{ 第 } \\
アルカリ添加量 & 石䖒濃度 $0.5 \%$ の場合 \\
cc 數 & 猋 態 \\
3.5 & OW 型+WO 型 \\
4.0 & OW 型粗粒 不安定 \\
4.5 & 同 上 \\
5.0 & 同 上 \\
5.5 & 同 上 \\
6.0 & 同 上
\end{tabular}

上表實驗と同樣な條件に依りて石㿵濃度 $0.1 \%$ の場合 を次表に示す。

$$
\text { 第十三表 }
$$

アルカリ添加量 石鹼湱度 $0.1 \%$ の場合

\begin{tabular}{clll} 
cc 數 & \multicolumn{2}{c}{ 狀 態 } & 48 時間後 \\
4.5 & OW 型 油箇大 & & \\
5.0 & 同 上 & & \\
5.5 & OW 型 油粒 & 不良 & 三曆分離 \\
6.0 & 同 上 & 同 & 上 \\
7.0 & 同 上 & 同 & 上 \\
8.0 & 同 上 & 同 上
\end{tabular}

アルカリ添加の効果に就いては全般を通じて乳化促進 は極めて著大なる効果を示す。安定度は一般に不安であ つて粒子は極めて粗大且不安定である。振蕰處理の場合 に比較してェマルジョンの狀態及び安定度は遥かに㸓る ものである。

以上の實驗に就いては次の樣に推定される。

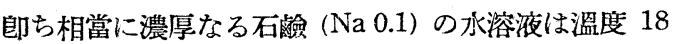
${ }^{\circ} \mathrm{C}$ に於乙約 80\% の中性膠貿粒子及び $21 \%$ の脂肪酸 イ オンミセルにより溶夜を構成する油の微粒子は此の石羷 水溶液中より中性膠質粒子 区びイオンミセルを吸着す る。然るに此等のイオンミセル中の脂肪酸は油の微粒子 に溶解するものである。上表實驗の如く此れに少量の> ルカリを添加してゆくときは石醶の解離を抑制すること と考へられる。從つてイオンミセル中の脂肪酸の量を減 少することとなる。即ち油に溶解する脂肪酸は減少し大 部分の石羷は中性膠質粒子としく「油一水」界面に吸 着されるものである。斯樣な理由に体りて油粒子の界面 に於ける吸着石睑膜を形成するに要する時間の減少及び 石雵の節約が考へられる。併し乍ら此の場合油粒子の界 面に吸着する膜は中性膠質粒子及びイオンミセルの外に 相當量のアルカリイオン $\left(\mathrm{Na}^{+}\right)$を有するものと推定さ
れるから OW 型エマルジョンの不安走も考慮されてく るのである。

$$
\text { 二 表 }
$$

120 時間:後

安定性 168 時間,後

480 時閽後

油餍分離

同上

水層分離傾向水管分離油層分離

同上同上同上

同上同上水䪪分離

\section{中性方レイ酸ソーダによるミミラル ターペンの乳化}

前項迄の實驗は石襝中に遊離脂肪酸が $26 \%$ 含有され たものであつた。本節は完全に中和したる、中性石䈩に 依る油の乳化條件と其の安定度を研究することに着手し た。先づ中性オレイン酸ソーダの製造にはオレイン酸を 完全に中和すべき苛性ソーダの量を求め無水アルコール を溶媒として中性オレイン酸ソーダを製造せり。然して 此の石羷は酸價測定の結果に依れば完全に中性である。

以下順次に表示也る實驗は乳化條件として乳化機處理 の前處理の種々なる場合に就いて行つたものである。次 に中性石鹼による油の乳化實驗に就いて乳化機のみの場 合を次表に示す。

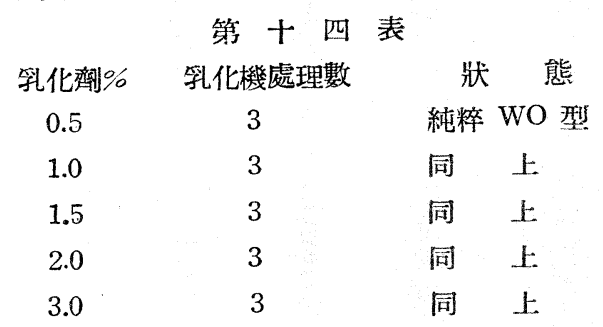

上表の場合と同樣な液に就いて振壍の効果を檢し結果 を次表に示卞。

\section{第十五表}

乳化劑\%第振晹時間 乳化機處理數 狀 態

\begin{tabular}{lllll}
0.5 & \multicolumn{2}{l}{ 連續15分 } & 3 & \multicolumn{2}{l}{ 純粹 WO 型 } \\
1.0 & 同 上 & 3 & 同 & 上 \\
1.5 & 同 上 & 3 & 同 & 上 \\
2.0 & 同 上 & 3 & 同 & 上 \\
3.0 & 同 上 & 3 & 同 & 上
\end{tabular}

上表實驗と同樣な處方によりて 24 時間放置處理の効 果を實驗し結果を次表に示す。 
第十 六 表

24 時間放置處理の効果

\begin{tabular}{|c|c|c|c|c|}
\hline 乳化劑\% & \multicolumn{2}{|c|}{ 乳化機處理數 } & & 態 \\
\hline 0.1 & \multicolumn{2}{|c|}{4} & \multicolumn{2}{|c|}{ 純粹 WO 型 } \\
\hline 0.2 & \multicolumn{2}{|c|}{4} & \multicolumn{2}{|c|}{ OW 型+WO 型 } \\
\hline 0.3 & \multicolumn{2}{|c|}{ 4.(3四で十分) } & OW 型 & 優良 \\
\hline 0.5 & $4 C$ 同 & 上) & 同 & 上. \\
\hline 1.0 & $4 C$ 同 & 上) & 同 & 上 \\
\hline 1.5 & $4 C$ 同 & 上) & 同 & 上 \\
\hline 2.0 & $4 C$ 同 & 上) & 同 & 上 \\
\hline 3.0 & $4 C$ 同 & 上) & 同 & 上 \\
\hline
\end{tabular}

[注意]第十六表は處方の液を 24 時間放置し其間に 3 四每回 10 分宛水平振浻機にて振晹す。湯浴溫 度 $60^{\circ}-70^{\circ} \mathrm{C}$ にて 2-3 分間處理後乳化機にて 3 包以上處理するを要寸。

上表と同樣な處方により 168 時間 (7 日) 放置處理の 效果を實驗し結果を次表に示す。

第十七表 168 時間放置處理の効果

\begin{tabular}{|c|c|}
\hline 乳化湴\% & 狀 \\
\hline 0.1 & OW 型+WO 型 \\
\hline 0.2 & OW 型 可良 \\
\hline 0.3 & OW 型 優良 \\
\hline 0.5 & 同上 \\
\hline
\end{tabular}

[注意] 168 時間 (7 日)放置處理中 24 時間に 2-3 分 間水平振温機處理を行つた。

中性石鹼に依る乳化能を述べるに第十四表及び第十五 表は石羷濃度の大小にかかはらず純 WO型を生成し振盪 に依る場合も乳化不可能であつた。

此れらのことより考へるに石油系炭化水素の乳化は水 中の石䖒が解離して油相中に脂肪酸を溶解せしむること が必須の條件と推定された。依つて:第十六表の如く 24 時間放置處理を行ひたるものは石羷濃度: $0.3 \%$ 以上にて 乳化可能である。次に第十七表は 168 時間 (7 日)放置 處理を行つたものである。安定度は 3 ヶ月以上 6 ヶ月の 安定性を保つことが出來る。但し 3 ヶ月以上は多少の轉 相を生ずるも外憼の變化はない。此等の理由に就いては 次の樣に考へられる郎ち長時間の放置により水中の石鹼 は解離平衡に達して脂肪酸を生ずる、此の脂肪酸は油相 中に溶解する。一方中性膠質粒子イオンミセル等は油相 の界面に吸着し同時に吸着促進も行はれるものと推定さ れる。

\section{中性オレイン酸リーダに依るミミラルターペン の乵化に對するオレイン酸添加の 勃果に就いて}

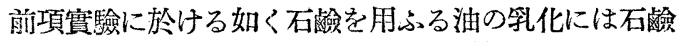
の解㒕によりて生ずる脂肪酸が油相に溶解しなければ乳 化不可能であると考へられた。依つて本項は石瞼夜にオ レイン酸渿加實驗を行ひエマルジョン中の油相中に溶解 するオレイン酸量の測定を行ふため次の如く實驗した結 果を次表に示す。

$$
\text { 第十八表 }
$$

中性オレイン酸ソ -ダ $1 \%$ の場合油 60 對水 40 添加量\% 酸 調合狀態振璗狀態乳化狀態

10 純 WO 型 純 WO 型 純 WO 型

20 同上同上同上

25 OW型+WO型 OW型+WO型 OW型+WO型

30 OW型粗粒 OW型粗粒 OW型優良

〔注意】オレイン酸添加量はオレイン酸ソーダに對する 重量\%である。

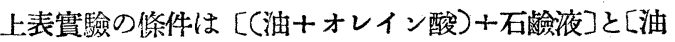

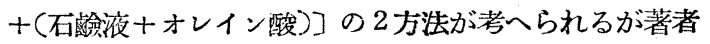
は乳化の理論に基いて前者を探用した。

表示せる如く添加オレイン酸量は $30 \%$ :必要とし乳 化機處理は 2 包以上を要する。安定度は 1 ヶ月であつて 此れ以上は分離してくる。

\section{オレイン酸ソーダを陉化、分散劑とするミミラ ルターペン及び亞麻仁油の新化能に就いて}

本項に於ては乳化、分散劑としてオレイン酸ソーダに 依るミネラルターペン及び亞㾁仁油の乳化能に就いて比 較检討を行ふ。

先づ亞麻伷のオレイン酸ソーダに依るェマルジョン の生成は生亞麻仁油及び數ポイズの粘度を有する重合亞 麻仁油の乳化能を支配する主因子は主として粘度であ る。油の酸價、沃素貨及び表面張力等の影響は全く無か つた。然るにミネラルターペンの場合はオレイン酸ソー ダ中の遊離オレイン酸の存在、其の含有量の多少及び過 剩アルカリの存在等に依つて著しく乳化能を異にし且つ 孚化機處理の前處理として振盪、加溫或は數十時間放置 等の處置が極めて有効であつて生成したる OW 型エマ ルジョンの安定度はミネラルターペンの場合特に顯著な る効果を示す。叉ミネラルターペンに於て一般にWO型 を生ずるに反し亞麻仁油の場合は OW 型を生ずる。然 
し乍ら前者の場合は OW 型は WO 型に比し安定度は遥 に大であるが後者は WO 型エマルジョンが大なる安定 度を示すものである上記の如くミネラルターペン及び亞 麻仁油の乳化現衷は全く相異れる性質と理論に依つて支 配されるものである。

\section{總括}

本報に於ては石險 (Na 0.1) を用ひてミネラルターペン を乳化する方法に關して實驗を行ひ乳化機で處理する。

寫真 說 明

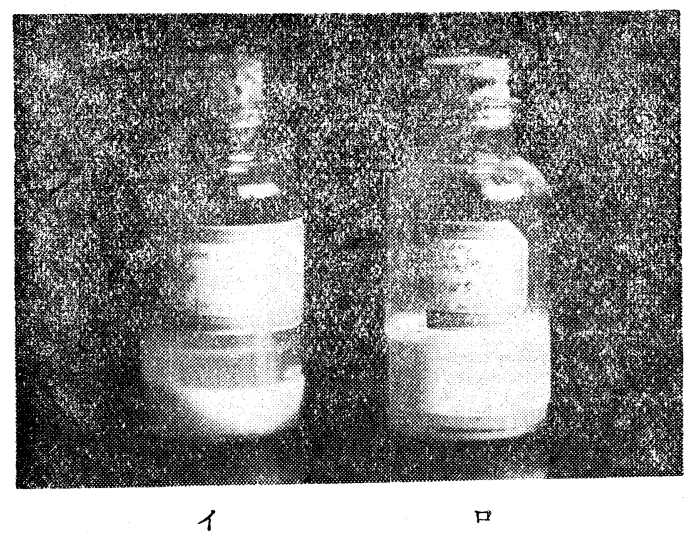

振浻の效果

ミネラルターペン 60 對水 40 石鹼 $1.5 \%$ の場合

$1 \mathrm{WO}$ 型 乳化機處理のみの場合

口 OW 型 乳化機處理の前處理として振盜處理 を行るる場合

本交 3 頁參照

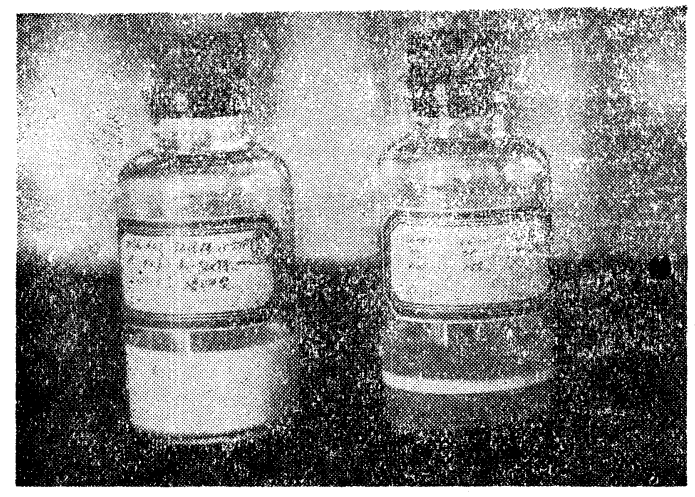

口

1

振盪の効果

ミネラルターペン 65 對水 35 石莶 $3.5 \%$ の場合

1WO 型 乳化機處理のみの場合

口 OW 型 乳化機處理の前處理として振盪處理 艺行へる場合

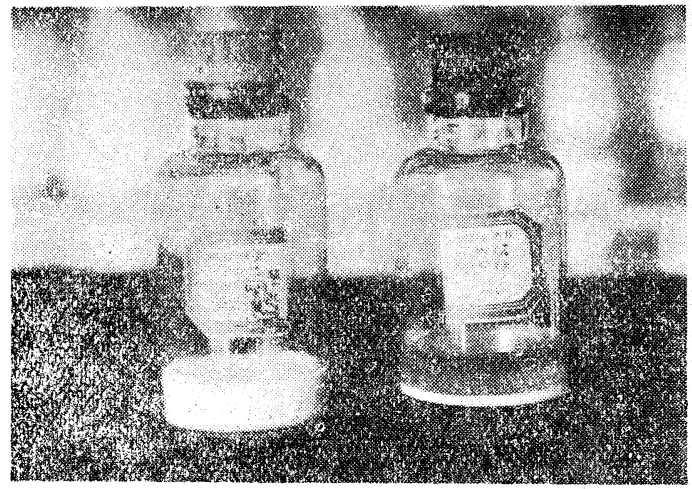

口

アルカリ症加の效果

ミネラルターペン 60 對水 40 石裣 $1 \%$ の場合

1 OW 型 アルカリ添加して乳化機處理を行へ る場合

口 WO 型 乳化機處理のみの場合

本交 4 頁參照

前處理として振湓、加溫及び長時間放置等の影響が大な ることを確認し此等適當なる處理を施すことに依りて乳 化困難なるミネラルターペンを極く微量の石羷を以て安 定なるエマルジョンを生成せしむることに成功した。劣 石险に關してはオレイン酸及びアルカリ添加等の効果を 檢討し前者の場合は振温のみに依つても相當良好なるエ マルジョンを得ることが出來た。然して中性石险の場合 は前處理として數日間の放置及び振盪處理を必要とする ことを認め此等エマルジョンの狀態を研究し且つ所見を 述べた。

\section{文獻}

W. Clayton: The Theory of Emulsions and Their Technical Treatment.

鮫島實三郎：膠質學

中江 大部：石敛製造化學

三雲 次郎：石翮の化學

武井 典夫：アミノ石鹼の特性に就いて(試驗所々報 3 號 $\mathrm{P}$ 121-122)

野中 正夫：石感に就いて(工業化學雜誌昭和三年第三 十編)

上野誠一・岡村善策：油脂實驗法

上野 誠一：油脂化學及び油脂各論

本交 3 頁參照 